\title{
Effects of Feeding Heat-Treated Colostrum on Passive Transfer of Immune and Nutritional Parameters in Neonatal Dairy Calves
}

\author{
J. L. Johnson, S. M. Godden, ${ }^{1}$ T. Molitor, T. Ames, and D. Hagman \\ Department of Veterinary Population Medicine, University of Minnesota, St Paul 55108
}

\begin{abstract}
The first objective of this study was to describe the effect of on-farm heat treatment of colostrum on colostral bacteria counts and IgG concentrations. The second objective was to describe the effect of feeding heattreated (vs. raw) colostrum on passive transfer of colostral immune and nutritional parameters in neonatal calves. Pooled batches of colostrum were mixed and divided equally: one half was fed raw whereas the other half was fed after heat treatment at $60^{\circ} \mathrm{C}$ for $60 \mathrm{~min}$ using a commercial on-farm batch pasteurizer. Colostrum samples were cultured for total bacteria count and total coliform count and analyzed for total IgG concentration. Forty-nine Holstein calves were fed either raw colostrum $(n=24)$ or heat-treated colostrum ( $\mathrm{n}=25$ ) within 1 to $2 \mathrm{~h}$ after birth. Serum samples collected from calves at $0 \mathrm{~h}$ (precolostrum) and $24 \mathrm{~h}$ (postcolostrum) were assayed for serum total protein; IgG, IgA, and IgM concentrations; peripheral total leukocyte counts; neutrophil counts; lymphocyte counts; lymphocyte phenotypes; vitamin A, vitamin E, cholesterol, and $\beta$-carotene concentrations. Serum samples collected from 2 - to 5 -d-old calves were tested for immunoglobulin function via a bovine viral diarrhea virus type I serum neutralization titer and for neutrophil bacterial opsonization activity. On-farm batch heat treatment of colostrum at $60^{\circ} \mathrm{C}$ for $60 \mathrm{~min}$ resulted in lower colostrum bacteria concentrations while maintaining colostral IgG concentration. Calves fed heattreated colostrum had significantly greater serum total protein and IgG concentrations at $24 \mathrm{~h}$, plus greater apparent efficiency of IgG absorption (total protein = $6.3 \mathrm{mg} / \mathrm{dL} ; \mathrm{IgG}=22.3 \mathrm{mg} / \mathrm{mL}$; apparent efficiency of absorption $=35.6 \%)$ compared with calves fed raw colostrum $(\mathrm{TP}=5.9 \mathrm{mg} / \mathrm{dL} ; \mathrm{IgG}=18.1 \mathrm{mg} / \mathrm{mL} ;$ apparent efficiency of absorption $=26.1 \%$ ). There was no effect of treatment on serum concentrations of IgA, IgM, vitamin $\mathrm{A}$, vitamin $\mathrm{E}$, cholesterol, $\beta$-carotene or vitamin
\end{abstract}

Received March 22, 2007.

Accepted July 31, 2007.

${ }^{1}$ Corresponding author: godde002@umn.edu
E:cholesterol ratio, or on serum bovine viral diarrhea virus type I serum neutralization titers. There was no difference between treatment groups when examining calf plasma total leukocyte counts, neutrophil counts, lymphocyte counts, or neutrophil opsonization activity. However, the latter results were considered inconclusive.

Key words: colostrum, calf, heat treatment, passive transfer of immunity

\section{INTRODUCTION}

First milking colostrum is an important source of nutrients, nonspecific immune factors, immunoglobulins, and other important immune factors, including maternal leukocytes, all of which protect the newborn calf against infectious disease in the first weeks and months of life (Davis and Drackley, 1998). Despite these benefits, colostrum can also represent one of the earliest potential exposures of dairy calves to infectious agents, including Mycobacterium avium ssp. paratuberculosis (Streeter et al., 1995; Sweeney, 1996). Other pathogens of concern that may be cultured from raw colostrum or milk include Mycoplasma spp. (Butler et al., 2000; Stabel et al., 2004), Escherichia coli, and Salmonella spp. (Smith et al., 1989; Spier et al., 1991; Stabel et al., 2004). These pathogens may be shed directly from an infected gland or result from contamination or bacterial proliferation caused by improper colostrum harvest, storage, or feeding procedures. Bacterial contamination of colostrum is of concern because pathogenic bacteria can act directly to cause diseases such as scours or septicemia. In addition, it is thought that bacteria in colostrum may interfere with passive absorption of colostral antibodies into the calf's circulation (James et al., 1981).

With recent increased interest in pasteurized milk feeding systems, producers have been curious to learn if there may also be benefits from feeding pasteurized colostrum. Early research pasteurizing colostrum using conventional methods and temperatures (as are typically used to pasteurize milk) yielded less than acceptable results including IgG denaturation and mild to marked increases in viscosity (Meylan et al., 1996; God- 
den et al., 2003; Stabel et al., 2004). Meylan et al. (1996) reported an average $12.3 \%$ loss of $\mathrm{Ig}$ in 5 -mL aliquots of bovine colostrum subjected to $63^{\circ} \mathrm{C}$ for $30 \mathrm{~min}$; increased viscosity was noted in $33 \%$ of the samples. When this pasteurization protocol was applied to large batches of colostrum on a commercial dairy farm, greater IgG denaturation ( 23.6 to $58.8 \%$ ) was reported (Godden et al., 2003). In the same study, calves fed raw colostrum had significantly greater serum IgG concentrations than calves fed colostrum pasteurized at $63^{\circ} \mathrm{C}$ for 30 min (Godden et al., 2003).

Despite these early failures, recent research has determined that problems with thickening or IgG denaturation can be avoided by using a lower-temperature, longer-time approach to heat treatment of colostrum. In most situations, heating colostrum at $60^{\circ} \mathrm{C}$ for 60 min in a commercial batch pasteurizer should be sufficient to maintain IgG concentrations and fluid characteristics while eliminating or significantly reducing important pathogens including Listeria monocytogenes, $E$. coli O157:H7, Salmonella enteritidis, and M. avium ssp. paratuberculosis (Godden et al., 2006; McMartin et al., 2006). The latter 2 studies, conducted in a laboratory setting, produced tentative recommendations to heattreat colostrum for $60 \mathrm{~min}$ at $60^{\circ} \mathrm{C}$. If successfully applied in a field setting, this protocol could significantly reduce or eliminate pathogen exposure from colostrum while preserving Ig concentration, Ig function, and colostrum feeding characteristics. However, further research was needed to determine if this heat-treatment protocol could be successfully replicated under on-farm conditions without reducing colostrum quality and without interfering with passive transfer of various colostral immune components to calves. The first objective of this study was to describe the effect of on-farm heat treatment of colostrum at $60^{\circ} \mathrm{C}$ for $60 \mathrm{~min}$ on colostrum characteristics including total plate counts (TPC; cfu/ $\mathrm{mL}$ ), total coliform counts (TCC; $\mathrm{cfu} / \mathrm{mL}$ ), and IgG concentrations $(\mathrm{mg} / \mathrm{mL})$. The second objective was to describe the effect of feeding heat-treated (vs. raw) colostrum on passive transfer of colostral immune and nutritional parameters. Parameters measured included serum Ig levels and activity [serum total protein (TP), IgG, IgA, IgM, apparent efficiency of absorption (AEA) of IgG, bovine viral diarrhea virus (BVDV) type I serum neutralization (SN) titer], plasma leukocyte levels, and activity (total leukocyte counts, neutrophil counts, lymphocyte counts, neutrophil opsonization activity), and selected nutritional parameters (vitamin A, vitamin E, cholesterol, and $\beta$-carotene).

\section{MATERIALS AND METHODS}

\section{Heat Treatment of Colostrum}

The study was conducted at a commercial dry and transition cow management facility near Baldwin, Wis- consin. When parturition was imminent, cows were moved to individual maternity pens. Newborn calves remained with the dam for 20 to $30 \mathrm{~min}$, but were removed before suckling could occur. First milking colostrum was harvested from cows within 30 to $60 \mathrm{~min}$ of calving and refrigerated until a pooled batch of approximately $16 \mathrm{~L}$ could be assembled (once per day). Each batch of colostrum was pooled, thoroughly mixed, and then split into 2 equal aliquots of approximately 8 $\mathrm{L}$ each. One paired 8-L aliquot was designated to be fed raw. From this, a 20-mL subsample of colostrum was collected and frozen at $-20^{\circ} \mathrm{C}$ for later IgG analysis and bacterial culture. The raw colostrum was then transferred into 3.8-L sanitized feeding bottles, covered, and refrigerated at $4^{\circ} \mathrm{C}$ until it could be fed. The second paired 8-L aliquot was heat-treated at $60^{\circ} \mathrm{C}$ for 60 min using a commercial on-farm batch pasteurization system (DT Silver, DairyTech Inc., Windsor, CO) at $60^{\circ} \mathrm{C}$ for $60 \mathrm{~min}$. Once cooled, a $20-\mathrm{mL}$ subsample of the heat-treated colostrum was collected and frozen at $-20^{\circ} \mathrm{C}$ for later IgG analysis and bacterial culture. The heat-treated colostrum was then also transferred into 3.8-L sanitized feeding bottles, covered, and refrigerated at $4^{\circ} \mathrm{C}$ until it could be fed. The 3.8-L bottles of raw and heat-treated refrigerated colostrum were identified by original batch number, date of assembly, and treatment (raw or heat-treated). Refrigerated colostrum was fed to calves within 1 to $36 \mathrm{~h}$ after assembly. Colostrum was discarded if it had not been fed by $48 \mathrm{~h}$ after assembly.

\section{Calf Enrollment and Sampling}

Protocols used for enrolling and treating calves within this study were approved by the University of Minnesota Institutional Animal Care and Use Committee. Calves from observed calvings were removed from the dam within 20 to 30 min of birth and before suckling could occur. To be eligible for enrollment, calves had to be singletons, weigh $\geq 31.7 \mathrm{~kg}$, and have a calving ease score $\leq 3$ ( 1 to 5 scale). A 10 -mL precolostral blood sample was collected from the jugular vein using $10-\mathrm{mL}$ serum and 10-mL EDTA Vacutainer tubes (BectonDickinson, Franklin Lakes, NJ). Calves were then systematically assigned (every other calf born) to receive $3.8 \mathrm{~L}$ of either raw $(\mathrm{n}=25)$ or heat-treated $(\mathrm{n}=25)$ colostrum. Systematic, rather than random, assignment to treatment groups was used to ensure that the age (duration of storage) of heat-treated and raw colostrum was approximately equal at the time of feeding, because the storage period will allow for bacterial growth in colostrum.

After assignment to a colostrum feeding group, the appropriate bottle of colostrum (heat-treated or raw) 
was removed from the refrigerator, the batch number recorded, and the colostrum warmed to approximately $38^{\circ} \mathrm{C}$ using a hot water bath heated to approximately $52^{\circ} \mathrm{C}$. Immediately before administration, an additional 20-mL aliquot of colostrum was collected and frozen for later bacterial culture to assess how much bacterial growth had occurred during the refrigeration period. Calves were then fed $3.8 \mathrm{~L}$ of colostrum using an esophageal tube feeder by 1 to $2 \mathrm{~h}$ of age. This colostrum feeding program (timing, volume, method of feeding) was routinely used on the study farm and is in accordance with current expert recommendations that promote feeding calves 10 to $12 \%$ of BW in colostrum at first feeding (Davis and Drackley, 1998). The average calf in the study weighed $40 \mathrm{~kg}$, so $3.8 \mathrm{~L}$ of colostrum was approximately $11 \%$ of BW. Date of birth, sex, treatment group (raw or heat-treated colostrum), calving ease score (1 to 5), and colostrum batch number fed were recorded for each calf.

Immediately after the colostrum feeding, calves were moved into a $4-\mathrm{m}^{2}$ pen and provided twice-daily feedings of $2 \mathrm{~L}$ of a commercial milk replacer containing $22 \%$ CP (milk protein-based) and $20 \%$ crude fat. At 24 $\mathrm{h}$ of age $( \pm 1 \mathrm{~h})$, two 10 -mL postcolostral blood samples were collected from the jugular vein using one $10-\mathrm{mL}$ serum and one 10-mL EDTA Vacutainer tube. After the 24-h blood samples were collected, calves were transported to a commercial heifer grower operation, usually between 24 and $48 \mathrm{~h}$ of age. Upon arrival at the calf grower, calves were housed in individual hutches until weaning. Calves had access to free-choice water and pelleted calf starter, and received $2 \mathrm{~L}$ of pasteurized nonsaleable milk feedings twice daily. Final blood samples were collected between 2 and $5 \mathrm{~d}$ of age. Samples were collected via jugular venipuncture using one $10-\mathrm{mL}$ serum and one 10-mL EDTA Vacutainer tube. Although not a study objective, health (treatment and mortality) events were recorded by the heifer grower until weaning at approximately $8 \mathrm{wk}$ of age.

\section{Colostrum Sample Analyses}

All frozen colostrum samples were transported, on ice packs, to the University of Minnesota Laboratory for Udder Health (St. Paul, MN). Samples were thawed to room temperature and underwent routine bacteriological culture to determine TPC and TCC (cfu/mL). Matching raw and heat-treated colostrum samples from each batch assembled were tested for total IgG concentration $(\mathrm{mg} / \mathrm{mL})$ using a turbidometric immunoassay (Olympus AU400e, Olympus America Inc., Melville, NY) using reagents from Midland Bioproducts Corp. (Boone, IA).

\section{Blood Sample Analyses for Ig Measures in Calves}

All precolostral (0 to $1 \mathrm{~h}$ ) and postcolostral (24 h) blood samples collected into serum (red top) Vacutainer tubes were refrigerated overnight, centrifuged, and the serum separated from the clot within $24 \mathrm{~h}$ of collection. Zero- and 24-h serum TP concentrations $(\mathrm{g} / \mathrm{dL})$ were determined using a commercially available hand-held refractometer method (VET 360, Reichert Inc., Depew, $\mathrm{NY}$ ). Sera were then stored at $-20^{\circ} \mathrm{C}$ until being submitted, on ice, to the Veterinary Diagnostic Laboratory, University of Minnesota (St. Paul). Zero- and 24-h serum IgM and IgA $(\mathrm{mg} / \mathrm{mL})$ concentrations were determined using a commercially available ELISA kit (Bethyl Laboratories, Montgomery, TX; Kruger et al., 2003). Zero- and 24-h serum total IgG concentrations were determined using a turbidometric immunoassay (Olympus AU400e, Olympus America Inc.) as described above. The AEA (\%) of IgG, a calculated measure that estimates what proportion of the total IgG mass fed is actually absorbed into the calf's circulation, was calculated using an accepted formula previously described by Quigley et al. (2002), when assuming a plasma volume of $9.9 \%$ of birth weight.

A microtitration SN assay was used to evaluate antibody activity in serum samples collected between 2 and $5 \mathrm{~d}$ of age. The SN test was performed by use of serial 2fold dilutions of heat-inactivated serum samples diluted from $1: 8$ to $1: 262,144$ in serum-free Eagle's minimal essential medium (MEM; Cellgro, Mediatech, Herndon, VA), incubated with a 100 - to 500 -tissue culture infective dose (TCID) $)_{50}$ of BVDV-Singer (type I) for $1 \mathrm{~h}$ at $5 \% \mathrm{CO}_{2}$ and $37^{\circ} \mathrm{C}$, and then incubated with bovine fetal turbinate cells in MEM media supplemented with $8 \%$ donor horse serum, at $5 \% \mathrm{CO}_{2}$ at $37^{\circ} \mathrm{C}$ for $144 \mathrm{~h}$. The antibody titer was reported as the greatest dilution showing complete inhibition of the cytopathic effect.

\section{Blood Sample Analyses for Leukocyte Measures in Calves}

All whole blood samples collected into EDTA Vacutainer tubes were refrigerated immediately, submitted on ice to the Veterinary Diagnostic Laboratory, University of Minnesota (St. Paul), and then analyzed within $8 \mathrm{~h}$ of collection. Zero- and 24-h total leukocyte counts and differential counts were completed by analyzing whole blood using an Abbott Cell-Dyn 3500 (Abbott Diagnostics Division, Mountain View, CA) and verified by smear (cells $/ \mu \mathrm{L})$. Additional smears were made immediately after collection and stained using WrightGiemsa stain. Manual differential counts were performed to obtain percentage lymphocyte and neutrophil counts. These percentages were then multiplied by the 
total white cell count to obtain absolute counts of lymphocytes and neutrophils (cells $/ \mu \mathrm{L}$ ).

Zero- and 24-h lymphocytes were isolated and phenotyped by layering approximately $11 \mathrm{~mL}$ of whole blood onto $3.5 \mathrm{~mL}$ of lymphocyte separation media (CellGro, Mediatech) in a 15-mL conical tube and centrifuging for $30 \mathrm{~min}$ at $1,000 \times \mathrm{g}$. The buffy coat layer was removed, washed with PBS, and centrifuged at $1,400 \times g$ for 10 $\mathrm{min}$. The supernatant was discarded and $1 \mathrm{~mL}$ of sterile water was added to the pellet to lyse any red blood cells. The sample was vortexed and $14 \mathrm{~mL}$ of PBS was added within 1 min of adding the water. The samples were again centrifuged at $1,400 \times \mathrm{g}$ for $10 \mathrm{~min}$ and the pellet resuspended in RPMI 1640 medium with L-glutamine and phenol red (CellGro, Mediatech). Cell concentrations were determined using the Abbott Cell-Dyn 3500 as above. Samples with a concentration of less than 5 $\times 10^{6}$ cells $/ \mu \mathrm{L}$ were not used for further analyses because of insufficient cellular concentration. Cells were diluted to a concentration of $2 \times 10^{6}$ cells $/ 200 \mu \mathrm{L}$ for further analysis. Lymphocytes were then stained with monoclonal antibodies against bovine CD-4, CD-8, CD14, and B cells (VMRD, Pullman, WA), as previously described (Le Jan, 1994). The cells were analyzed using a Becton-Dickinson FACScan flow cytometer, utilizing CellQuest software. The acquisition settings were those usually used for the analysis of peripheral blood leukocytes. The electronic gates were set on the cell populations based on the forward-angle vs. the right angle scatter histograms. Results obtained were percentage of cells gated. The percentages were then multiplied by the absolute lymphocyte count to determine the absolute count of CD4, CD8, CD14, and B lymphocytes.

Whole blood samples collected from calves at 2 to 5 $\mathrm{d}$ of age were used to assess neutrophil opsonization activity, the ability of neutrophils to phagocytize bacteria, using a previously described method (RiedelCaspari and Schmidt, 1991c). One milliliter of EDTAanticoagulated whole blood was incubated with $2 \times 10^{8}$ cfu of $E$. coli in siliconized ( $5 \%$ dicholesteryl mesaconate, Merck, Whitehouse Station, NJ) and prewarmed glass tubes for $30 \mathrm{~min}$ in a $37^{\circ} \mathrm{C}$ water bath. The tubes were centrifuged at $4^{\circ} \mathrm{C}$ and $1,400 \times g$ for $10 \mathrm{~min}$ immediately after the end of the incubation period. The leukocyte layer was removed and used to prepare blood smears. The percentage of active phagocytic cells incorporating $E$. coli was determined after Wright-Giemsa staining of the smears (Riedel-Caspari and Schmidt, 1991c).

\section{Blood Sample Nutrient Analyses in Calves}

Zero- and 24-h serum samples were analyzed for concentrations of vitamin A $(\mathrm{ng} / \mathrm{mL})$, vitamin $\mathrm{E}(\mu \mathrm{g} / \mathrm{mL})$, cholesterol $(\mathrm{mg} / \mathrm{dL})$, and $\beta$-carotene $(\mu \mathrm{g} / \mathrm{mL})$ at the $\mathrm{Nu}$ trition Laboratory, Diagnostic Center for Population and Animal Health, College of Veterinary Medicine, Michigan State University (East Lansing).

\section{Statistical Analysis}

Descriptive statistics were generated to describe calf and dam characteristics, colostrum measures, and calf serum measures for the 2 treatment groups. Linear regression analysis (PROC MIXED in SAS, version 9.1; SAS Institute Inc., Cary, NC) was used to describe the relationship between colostrum treatment group (heat treated vs. raw: explanatory variable) and each of the following continuous dependent variables of interest for colostrum: colostrum IgG concentration $(\mathrm{mg} / \mathrm{mL})$; $\log _{10}(\mathrm{TPC}, \mathrm{cfu} / \mathrm{mL})$ and $\log _{10}(\mathrm{TCC}, \mathrm{cfu} / \mathrm{mL})$ in colostrum at processing (immediately before refrigeration); and $\log _{10}$ (TPC, cfu $/ \mathrm{mL}$ ) and $\log _{10}(\mathrm{TCC}, \mathrm{cfu} / \mathrm{mL}$ ) in colostrum immediately before feeding (after refrigeration). The same approach was used to describe the relationship between colostrum treatment group (explanatory variable) and the concentrations of each of the following continuous dependent variables of interest for calf serum at both 0 and $24 \mathrm{~h}$ of age: TP $(\mathrm{g} / \mathrm{dL}), \operatorname{IgG}(\mathrm{mg} / \mathrm{mL})$, $\operatorname{IgA}(\mathrm{mg} / \mathrm{mL}), \operatorname{IgM}(\mathrm{mg} / \mathrm{mL}), \log _{10}$ (leukocytes)(cells $\left./ \mu \mathrm{L}\right)$, $\log _{10}$ (lymphocytes) (cells/ $\mu \mathrm{L}$ and \%), $\log _{10}$ (neutrophils) (cells/ $\mu \mathrm{L}$ and \%), $\log _{10}(\mathrm{CD} 4$ lymphocytes) (cells/ $/ \mathrm{L}$ and $\%), \quad \log _{10}(\mathrm{CD} 8$ lymphocytes) (cells $/ \mu \mathrm{L}$ and \%), $\log _{10}(\mathrm{CD} 14$ lymphocytes) (cells/ $\mu \mathrm{L}$ and $\%), \log _{10}$ (B lymphocytes) (cells/ $\mu \mathrm{L}$ and \%), vitamin A (ng/mL), vitamin $\mathrm{E}(\mu \mathrm{g} / \mathrm{mL})$, cholesterol $(\mathrm{mg} / \mathrm{dL})$, vitamin E:cholesterol $\times 10^{-3}$, and $\beta$-carotene $(\mu \mathrm{g} / \mathrm{mL})$, AEA IgG $(\%)$ at $24 \mathrm{~h}$, and the $\log _{2}$ BVDV Type-1 SN titer and neutrophil opsonization activity (\%) at 2 to $5 \mathrm{~d}$. Parameters describing calf characteristics (birth weight, kg; age at first feeding, min) and dam characteristics (parity; calving ease score, 1 to 3 ) were offered as additional covariates into each of the regression models. However, none of these terms was significant and none interacted with the variable describing colostrum treatment group, and so they were subsequently removed from the final models. Furthermore, a parameter describing age (d) at collection of the 2 to $5 \mathrm{~d}$ sample was offered into the models describing BVDV Type-1 SN titer and neutrophil opsonization activity, but was not significant and did not interact with the variable describing colostrum treatment group, and so was subsequently removed from the final models. All models controlled for batch number as a random effect to control for clustering introduced by the fact that calves in both treatment groups were fed colostrum from the same original batches of origin. 
Table 1. Description of calf and colostrum parameters ${ }^{1}$

\begin{tabular}{|c|c|c|c|}
\hline \multirow[b]{2}{*}{ Parameter $^{2}$} & \multicolumn{2}{|c|}{ Treatment group } & \multirow[b]{2}{*}{$P$-value } \\
\hline & Raw & Heat-treated & \\
\hline \multicolumn{4}{|l|}{ Colostrum characteristics } \\
\hline IgG concentration $(\mathrm{mg} / \mathrm{mL})$ & $\begin{array}{l}72.6(2.7) \\
(48.9 \text { to } 95.0)\end{array}$ & $\begin{array}{l}67.3(2.3) \\
(47.9 \text { to } 88.2)\end{array}$ & 0.45 \\
\hline TPC processing $\left(\log _{10} \mathrm{cfu} / \mathrm{mL}\right)$ & $\begin{array}{l}3.95(0.21) \\
(2.6 \text { to } 6.05)\end{array}$ & $\begin{array}{l}1.15(0.26) \\
(0 \text { to } 4.08)\end{array}$ & $<0.0001$ \\
\hline TCC processing $\left(\log _{10} \mathrm{cfu} / \mathrm{mL}\right)$ & $\begin{array}{l}3.62(0.22) \\
(2.18 \text { to } 5.64)\end{array}$ & $\begin{array}{l}1.18(0.25) \\
(0 \text { to } 3.88)\end{array}$ & $<0.0001$ \\
\hline TPC feeding $\left(\log _{10} \mathrm{cfu} / \mathrm{mL}\right)$ & $\begin{array}{l}4.67(0.25) \\
(2.18 \text { to } 6.89)\end{array}$ & $\begin{array}{l}2.92(0.22) \\
(0 \text { to } 4.78)\end{array}$ & $<0.0001$ \\
\hline TCC feeding $\left(\log _{10} \mathrm{cfu} / \mathrm{mL}\right)$ & $\begin{array}{l}4.38(0.27) \\
(1.7 \text { to } 6.3)\end{array}$ & $\begin{array}{l}2.81(0.20) \\
(0.70 \text { to } 4.32)\end{array}$ & $<0.0001$ \\
\hline \multicolumn{4}{|l|}{ Calf characteristics } \\
\hline Mean birth weight (kg) & $\begin{array}{l}40.1(0.81) \\
(31.8 \text { to } 45.5)\end{array}$ & $\begin{array}{l}40.4(0.79) \\
(33.2 \text { to } 50.0)\end{array}$ & 0.80 \\
\hline Mean age at first feeding (min) & $\begin{array}{l}51(5.3) \\
(10 \text { to } 120)\end{array}$ & $\begin{array}{l}53(7.3) \\
(15 \text { to } 180)\end{array}$ & 0.83 \\
\hline Median parity of dam & $\begin{array}{l}2 \\
(1 \text { to } 6)\end{array}$ & $\begin{array}{l}2 \\
(1 \text { to } 6)\end{array}$ & 0.18 \\
\hline Median calving ease score & $\begin{array}{l}1 \\
(1 \text { to } 2)\end{array}$ & $\begin{array}{l}1 \\
(1 \text { to } 3)\end{array}$ & 0.38 \\
\hline
\end{tabular}

${ }^{1}$ Reported values reflect mean (SE) with range in parentheses in the row below.

${ }^{2} \mathrm{TPC}=$ total plate count; $\mathrm{TCC}=$ total coliform count.

Logistic regression analysis (Proc GENMOD in SAS, version 9.1) was used to describe the relationship between treatment group and risk for a preweaning treatment event and risk for a preweaning mortality event in the first 8 wk of life. Final significance was declared at $P<0.05$ for all models.

\section{RESULTS}

\section{Effect of Heat Treatment on Colostrum Bacteria Counts and IgG Concentration}

There was no difference in the mean $( \pm \mathrm{SE})$ colostral IgG concentration for heat-treated vs. raw colostrum $(67.3 \mathrm{mg} / \mathrm{mL} \pm 2.3$ vs. $72.6 \mathrm{mg} / \mathrm{mL} \pm 2.7 ; P=0.45$; Table 1). Mean $( \pm S E)$ bacteria counts were significantly lower immediately after collection and processing in heattreated colostrum $(\mathrm{TPC}=1.15 \pm 0.26$; $\mathrm{TCC}=1.18 \pm$ 0.25 ) compared with raw colostrum $(\mathrm{TPC}=3.95 \pm 0.21$; TCC $=3.62 \pm 0.22$ ). Similarly, at the time of feeding, bacteria counts, although increased in both groups, were still significantly lower in heat-treated colostrum $(\mathrm{TPC}=2.92 \pm 0.22 ; \mathrm{TCC}=2.81 \pm 0.20)$ compared with raw colostrum $(\mathrm{TPC}=4.67 \pm 0.25 ; \mathrm{TCC}=4.38 \pm 0.27$; $P<0.0001$; Table 1).

\section{Effect of Feeding Heat-Treated Colostrum on Serum Ig Concentrations and Activity in Calves}

Fifty calves, 25 per treatment group, were originally enrolled in the study. One calf in the control group was omitted from final analysis because it had a reported calving ease score $>3$. Calf birth weights, time to first feeding, median parity of the dam, and median calving ease score did not vary significantly between treatment groups (Table 1). When measured at $0 \mathrm{~h}$ (precolostral sample), there was no difference between treatment groups when observing serum $\mathrm{TP}$, IgG, IgA, or IgM measures. However, 24-h serum concentrations of TP and IgG were greater for calves fed heat-treated colostrum $(\mathrm{TP}=6.3 \pm 0.1 \mathrm{~g} / \mathrm{dL} ; \operatorname{IgG}=22.3 \pm 0.9 \mathrm{mg} / \mathrm{mL})$ vs . calves fed raw colostrum $(\mathrm{TP}=5.9 \pm 0.1 \mathrm{~g} / \mathrm{dL} ; \mathrm{IgG}=18.1$ $\pm 1.2 \mathrm{mg} / \mathrm{mL} ; P=0.0011$; Table 2). Apparent efficiency of absorption of IgG (\%) was also greater for calves fed heat-treated colostrum $(\mathrm{AEA}=35.6 \pm 0.02 \%)$ vs. calves fed raw colostrum (AEA $=26.1 \pm 0.02 \% ; P=<0.0001)$. There was no effect of treatment on 24 -h serum concentrations of IgM or IgA (Table 2). Also, there was no difference in BVDV type I SN titer for calves receiving heat-treated $\left[\log _{2}(\right.$ titer $)=9.7 \pm 0.3 ; 8$ to 13$]$ vs. raw $\left[\log _{2}(\right.$ titer $)=9.5 \pm 0.3 ; 8$ to 12$]$ colostrum $(P=0.92)$.

\section{Effect of Feeding Heat-Treated Colostrum on Plasma Leukocyte Counts Activity}

Because samples for cell assays were not initially collected during the first few weeks of the study, samples were not available from all calves to analyze leukocyte counts. Only 20 samples from the heat-treated group and 21 samples from the raw group were available for analysis of peripheral leukocyte counts, lymphocyte counts, and neutrophil counts. Additionally, 
Table 2. Serum immunoglobulin concentration and activity in calves receiving raw $(n=24)$ or heat treated $(n=25)$ colostrum ${ }^{1}$

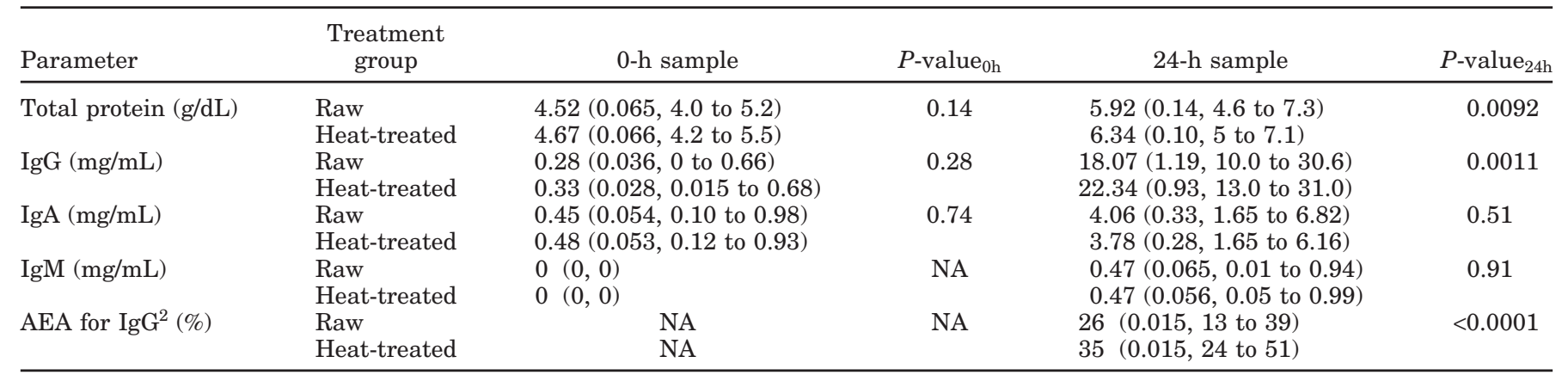

\footnotetext{
${ }^{1}$ Reported values reflect mean (SE, range).
}

${ }^{2} \mathrm{AEA}=$ apparent efficiency of absorption.

not all samples yielded enough cells to perform the lymphocyte phenotyping assay, resulting in 12 and 16 samples for the raw group and 11 and 14 for the heattreated group ( 0 - and 24 -h samples, respectively). These missing leukocyte measures for calves enrolled in the early part of the study occurred uniformly in both colostrum treatment groups, so this is not expected to introduce bias to study findings.

There were no differences between treatment groups, at 0 or $24 \mathrm{~h}$, in total peripheral white blood cell counts, neutrophil counts or percentages, total lymphocyte counts or percentages, or counts or percentages of CD4, CD8, CD14, and B lymphocytes (Table 3). Finally, there was no effect of treatment when comparing the mean $( \pm \mathrm{SE}$; range) percentage of neutrophils that engulfed bacteria for calves receiving raw colostrum $(31.3 \pm 1.72$; 19 to $43 \%)$ vs. heat-treated colostrum $(28.2 \pm 1.78 ; 12$ to $44 \% ; P=0.23)$.

\section{Effect of Feeding Heat-Treated Colostrum on Serum Nutrient Parameters}

Serum cholesterol concentrations at $0 \mathrm{~h}$ were greater for calves fed raw $(26.4 \pm 1.2 \mathrm{mg} / \mathrm{dL})$ vs. heat-treated $(22.0 \pm 1.1 \mathrm{mg} / \mathrm{dL})$ colostrum $(P=0.01)$. Given that these samples were collected before administration of the colostrum treatment under study, this difference is likely to be a spurious result. When measured at 24 $\mathrm{h}$, there was no difference in serum cholesterol levels between treatment groups. Similarly, there was no difference between treatment groups in serum levels of vitamin $\mathrm{A}$, vitamin $\mathrm{E}, \beta$-carotene, or vitamin $\mathrm{E}$ :cholesterol $\times 10^{-3}$ ratio when measured at either 0 or $24 \mathrm{~h}$ of age $(P>0.05$; Table 4$)$.

\section{Effect of Feeding Heat-Treated Colostrum on Preweaning Health}

Although the study was not originally designed with a sufficient sample size to adequately investigate treat- ment effects on calf health, health data are reported. There was no effect of treatment on calf health. For calves receiving either raw or heat-treated colostrum, $50 \%(12 / 24)$ or $60 \%(15 / 25)$ of calves had one or more treatment events recorded before weaning $(8 \mathrm{wk})$, respectively $(P=0.49)$, and $16.7 \%(4 / 24)$ or $12 \%(3 / 25)$ of calves died before weaning, respectively $(P=0.62)$.

\section{DISCUSSION}

\section{Effect of Heat Treatment on Colostrum Bacteria Counts and IgG Concentration}

Previous laboratory studies have reported success in reducing or eliminating inoculated pathogens while preserving protective antibodies and viscosity characteristics, when colostrum was heat-treated at $60^{\circ} \mathrm{C}$ for 60 min (Godden et al., 2006; McMartin et al., 2006). This study reported the effects of heat-treating colostrum at $60^{\circ} \mathrm{C}$ for 60 min using a commercial on-farm batch pasteurizer on colostrum characteristics and passive transfer of colostral components in calves. Similar to results from previous laboratory studies, on-farm heat treatment in a commercial batch pasteurizer at $60^{\circ} \mathrm{C}$ for 60 min resulted in no significant change in colostral IgG concentrations, but significantly reduced the TPC and TCC. Mean TPC at time of feeding for both treatment groups were below the current industry recommended upper limit of $100,000 \mathrm{cfu} / \mathrm{mL}$ for clean colostrum (McGuirk and Collins, 2004). As has been reported in previous studies, bacterial counts increased in both raw and heat-treated colostrum when stored in the refrigerator for as little as $24 \mathrm{~h}$ (Stewart et al., 2005).

\section{Effect of Feeding Heat-Treated Colostrum on Serum Ig Concentrations and Activity in Calves}

The most exciting result from this study was that feeding heat-treated colostrum resulted in greater serum IgG concentrations in calves, despite the fact that 
Table 3. Plasma leukocyte measurements in calves receiving raw or heat-treated colostrum ${ }^{1}$



${ }^{1}$ Reported values reflect mean (SE, range).

${ }^{2}$ Absolute counts of lymphocytes and neutrophils determined by multiplying differential (percentage) counts by total white count.

${ }^{3} \mathrm{Absolute}$ counts of lymphocyte phenotypes determined by multiplying the percentage cells gated by the absolute lymphocyte count.

calves in both treatment groups were fed the same total mass of IgG at the same time after birth and using the same feeding method. The authors hypothesize that greater serum IgG concentrations could have resulted because calves receiving heat-treated colostrum were able to absorb a greater proportion of the total mass of IgG presented to the small intestine. This hypothesis is supported by the observation that calves fed heattreated colostrum had significantly greater values for estimated AEA (\%) of IgG.

One possible explanation for the observed difference in AEA (\%) of IgG between the 2 colostrum treatment groups may be offered by the phenomenon of lactogenic immunity provided by colostrum (Corley et al., 1977; Acres, 1985; Saif and Smith, 1985; Nagy, 2002). Antibodies in colostrum have been shown to bind pathogens present in the gut before absorption can occur. By reducing the number of pathogens in heat-treated colostrum, and as a result, the number of pathogens in the gut, more antibodies are potentially free for absorption. Another potential explanation for an increase in AEA of $\operatorname{IgG}(\%)$ is lack of bacterial interference at the receptors that are responsible for Ig absorption. Bacteria can bind the nonspecific receptors on neonatal enterocytes, thus

Table 4. Nutritional parameters for calves receiving raw $(\mathrm{n}=24)$ or heat-treated $(\mathrm{n}=25)$ colostrum $^{1}$

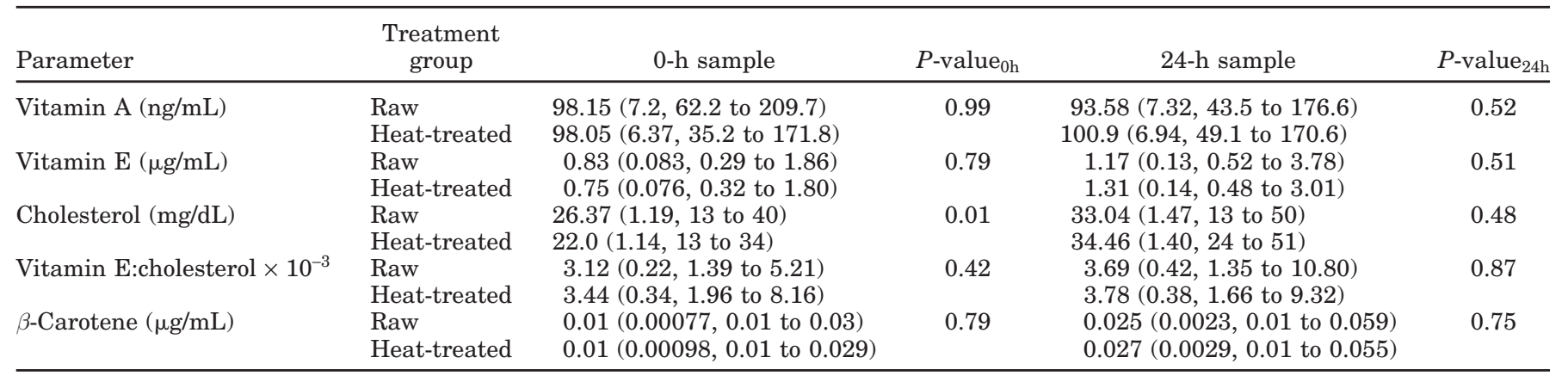

${ }^{1}$ Reported values reflect mean (SE, range). 
reducing the number of receptors available for Ig uptake (James and Polan, 1978; James et al., 1981; Staley and Bush, 1985). Again, by reducing the number of pathogens in heat-treated colostrum, there is potentially less interference at receptors to block absorption of available Ig.

It is interesting that the AEA (\%) of IgG was significantly improved by feeding heat-treated colostrum containing very low levels of bacteria, even though the TPC in the control group (raw colostrum) was already below the industry-recommended cutpoint of 100,000 cfu/mL. This suggests that this current industry-recommended cutpoint might not be optimal, insofar as these levels of bacteria may still negatively affect passive absorption of IgG. As such, future studies should further investigate whether the current recommended TPC cutpoint of $100,000 \mathrm{cfu} / \mathrm{mL}$ is optimal for calf health.

No significant differences were noted when comparing serum concentrations of IgA and IgM at $24 \mathrm{~h}$. This may be due to the fact that these Ig comprise only 5 to $10 \%$ of the total Ig present in colostrum, making relatively small differences in measures difficult to detect, if present at all (Davis and Drackley, 1998). The fact that there was no difference in serum BVDV type I titer suggests that heat treatment of colostrum did not harm antibody activity. This agrees with a previous laboratory study that reported no effect of heat-treating colostrum at $60^{\circ} \mathrm{C}$ for $60 \mathrm{~min}$ on antibody binding activity in colostrum (McMartin et al., 2006).

\section{Effect of Feeding Heat-Treated Colostrum on Plasma Leukocyte Counts and Activity in Calves}

The importance and roles of colostral leukocytes in stimulating development of the calf's own immune system have recently begun to be recognized (RiedelCaspari and Schmidt, 1991a,b,c; Riedel-Caspari et al., 1991; Tuboly and Bernath, 2002). It is generally expected that heat treatment will denature some, if not all, of the leukocytes in colostrum. Thus, it was anticipated that calves fed heat-treated colostrum would experience some relative reduction in some or all leukocyte measures at $24 \mathrm{~h}$. However, no treatment differences were observed in peripheral total leukocyte counts, neutrophil counts, lymphocyte counts, or lymphocyte phenotypes at $24 \mathrm{~h}$. Furthermore, although it was anticipated that peripheral leukocyte counts would be increased in 24-h samples compared with 0 -h samples, due to absorption of colostral leukocytes, leukocyte count changes from 0 to $24 \mathrm{~h}$ were either nonexistent or very minor for calves in either treatment group. Total leukocyte counts and differential counts were all within biologically normal ranges for young calves (Smith, 2002), but to our knowledge, the distribution of lympho- cyte phenotypes in precolostral and postcolostral neonatal calves has not been published. However, the distribution observed was similar to that found in neonatal piglets and lambs (Sheldrake and Husband, 1985; Le Jan, 1994). Finally, there was no significant difference noted in the phagocytic activity of the neutrophils in calves between the colostrum treatment groups. The latter results are comparable with those reported for neonatal calves in other studies (Riedel-Caspari and Schmidt, 1991c).

One explanation for the failure to see an increase in peripheral leukocyte counts at 24 vs. $0 \mathrm{~h}$ may be that calves in both treatment groups failed to absorb colostral leukocytes. Studies of other species, including piglets, have reported that maternal colostral leukocytes from the neonate's own dam are selectively absorbed by the neonate, whereas colostral leukocytes from an animal other than the dam may not be absorbed (Tuboly and Bernath, 2002). Because the colostrum used in the current study was from a pooled source of cows other than the dam, it is possible that calves in both treatment groups failed to absorb colostral leukocytes. Whether bovine neonates selectively absorb colostral leukocytes, from their own dam or from any cow, still needs to be determined. Another possible explanation is that colostral leukocytes were absorbed, but their numbers were dwarfed by the relatively large numbers of the calf's own leukocytes, making their addition relatively undetectable with the assays used in this study. Alternately, it may be possible that absorbed cells trafficked very quickly to lymphoid tissue and so went undetected in the peripheral circulation (LaMotte and Eberhart, 1976; Reber et al., 2005, 2006).

In summary, although the results of this study would seem to suggest that there was no negative effect of treatment on neonatal plasma leukocyte counts at 24 $\mathrm{h}$, these results should be considered inconclusive. Further studies, using different study designs and outcome measures, will be required to determine i) if neonatal calves can absorb non-dam colostral leukocytes and ii) if passive absorption of colostral cellular immune fractions, or function of these cell fractions, are affected by heat-treating colostrum at $60^{\circ} \mathrm{C}$ for $60 \mathrm{~min}$.

\section{Effect of Feeding Heat-Treated Colostrum on Serum Nutrient Parameters Calves}

There was no significant difference in serum vitamin A concentrations between the 2 treatment groups at 24 h. Most calves fell within the acceptable range of serum vitamin A for neonates (50 to $150 \mathrm{ng} / \mathrm{mL}$ ), with none of the study calves being considered deficient in vitamin A $(<20 \mathrm{ng} / \mathrm{mL}$; J. Zyskowski, Michigan State University, East Lansing; personal communication). This is similar 
to findings validating the heat stability of this nutrient in human and bovine milk (Ovesen et al., 1996; Sieber et al., 1996). However, it was interesting to note that no increase in serum vitamin A levels was observed to occur between 0 and $24 \mathrm{~h}$ for either treatment group. The authors have no explanation for this observation, because it was assumed that serum vitamin A levels would be increased at $24 \mathrm{~h}$ (vs. $0 \mathrm{~h}$ ) due to absorption of the vitamin from colostrum. It has been shown that vitamin $\mathrm{A}$ is stable in microwave-heated milk up to $83^{\circ} \mathrm{C}$ (Sieber et al., 1996). Because the heat treatment protocol only reached temperatures of $60^{\circ} \mathrm{C}$, it was assumed that vitamin A was not denatured by this process.

Significant increases in serum vitamin E, cholesterol, $\beta$-carotene, and vitamin E:cholesterol ratio occurred between 0 and $24 \mathrm{~h}$ for calves in both treatment groups. These parameters were not different in 24-h-old calves fed heat-treated vs. raw colostrum. All calves in the study fell well above the range considered adequate for neonatal calves (0.7 to 2.1) for vitamin E:cholesterol ratio (J. Zyskowski, Michigan State University, East Lansing; personal communication). However, the reference range used by Zyskowski was established using calves ranging in age from 1 to $7 \mathrm{~d}$, whereas results for the current study were derived from 0 - or 24 -h samples. Because reference ranges for $\beta$-carotene were not previously available for neonatal calves, the results from this study may provide a useful baseline for other researchers. Overall, heat-treatment of colostrum did not appear to have a detrimental effect on serum levels of the various nutrient parameters measured in this study.

\section{CONCLUSIONS}

Batch heat-treatment of colostrum at $60^{\circ} \mathrm{C}$ for $60 \mathrm{~min}$ on a commercial dairy farm resulted in reduced bacteria concentrations in colostrum while preserving the colostral Ig concentration. Apparent efficiency of absorption of IgG and calf serum IgG and TP concentrations at 24 $h$ of age were significantly greater for calves fed heattreated (vs. raw) colostrum. Serum Ig function and serum concentrations of IgA, IgM, vitamin A, vitamin $\mathrm{E}$, cholesterol, $\beta$-carotene, and vitamin E:cholesterol ratio did not differ between calves fed heat-treated vs. raw colostrum at $24 \mathrm{~h}$ of age. Although there did not appear to be any deleterious effects of feeding heat-treated colostrum on total leukocyte counts, neutrophil counts, lymphocyte counts, or neutrophil opsonization activity in calf plasma, these results were considered inconclusive. Further research is required to better describe the possible effects of heat treatment on colostral leukocyte function and activity. Future studies will also need to explore the short- and long-term calf health, performance, and economic implications of adopting the practice of feeding heat-treated colostrum on commercial dairies.

\section{ACKNOWLEDGMENTS}

This project was funded by the Minnesota Rapid Agricultural Response Fund. We would like to thank Megan Becker, Krista Steffenhagen, Grant Williams, and Megan Bandrick for their assistance with sample collection and laboratory analysis. We gratefully acknowledge the support provided by the owners and management of the Transition Management Facility in facilitating the completion of this project.

\section{REFERENCES}

Acres, S. D. 1985. Enterotoxigenic Escherichia coli infections in newborn calves: A review. J. Dairy Sci. 68:229-256.

Butler, J. A., S. A. Sickles, C. J. Johanns, and R. F. Rosenbusch. 2000. Pasteurization of discard mycoplasma mastitic milk used to feed calves: Thermal effects on various mycoplasma. J. Dairy Sci. 83:2285-2288.

Corley, L. D., T. E. Staley, L. J. Bush, and E. W. Jones. 1977. Influence of colostrum on transepithelial movement of Escherichia coli O55. J. Dairy Sci. 60:1416-1421.

Davis, C. L., and J. K. Drackley. 1998. The Development, Nutrition and Management of the Young Calf. Iowa State University Press, Ames.

Godden, S., S. McMartin, J. Feirtag, J. R. Stabel, R. Bey, S. Goyal, L. Metzger, J. Fetrow, S. J. Wells, and H. Chester-Jones. 2006. Heat treatment of bovine colostrum II: Effects of heating duration on pathogen viability and immunoglobulin G. J. Dairy Sci. 89:3476-3483.

Godden, S. M., S. Smith, J. M. Feirtag, L. R. Green, S. J. Wells, and J.P. Fetrow. 2003. Effect of on-farm commercial batch pasteurization of colostrum on colostrum and serum immunoglobulin concentrations in dairy calves. J. Dairy Sci. 86:1503-1512.

James, R. E., and C. E. Polan. 1978. Effect of orally administered duodenal fluid on serum proteins in neonatal calves. J. Dairy Sci. 61:1444-1449.

James, R. E., C. E. Polan, and K. A. Cummins. 1981. Influence of administered indigenous microorganisms on uptake of [iodine125] gamma-globulin in vivo by intestinal segments of neonatal calves. J. Dairy Sci. 64:52-61.

Kruger, E. F., B. L. Boyd, and L. M. Pinchuk. 2003. Bovine monocytes induce immunoglobulin production in peripheral blood B lymphocytes. Dev. Comp. Immunol. 27:889-897.

LaMotte, G. B., and R. J. Eberhart. 1976. Blood leukocytes, neutrophil phagocytosis, and plasma corticosteroids in colostrum-fed and colostrum-deprived calves. Am. J. Vet. Res. 37:1189-1193.

Le Jan, C. 1994. A study by flow cytometry of lymphocytes in sow colostrum. Res. Vet. Sci. 57:300-304.

McGuirk, S. M., and M. Collins. 2004. Managing the production, storage and delivery of colostrum. Vet. Clin. North Am. Food Anim. Pract. 20:593-603.

McMartin, S., S. Godden, L. Metzger, J. Feirtag, R. Bey, J. R. Stabel, S. Goyal, J. Fetrow, S. J. Wells, and H. Chester-Jones. 2006. Heat-treatment of bovine colostrum I: Effects of temperature on viscosity and immunoglobulin G. J. Dairy Sci. 89:2110-2118.

Meylan, M., D. M. Rings, W. P. Shulaw, J. J. Kowalski, S. BechNielsen, and G. F. Hoffsis. 1996. Survival of Mycobacterium paratuberculosis and preservation of immunoglobulin $\mathrm{G}$ in bovine colostrum under experimental conditions simulating pasteurization. Am. J. Vet. Res. 57:1580-1585. 
Nagy, D. W. 2002. Recent advances in the understanding of passive transfer in calves. Pages 310-312 in Proc. 20th Annu. Mtg. Am. Coll. Intern. Vet. Med. ACIVM, Dallas, TX.

Ovesen, L., J. Jakobsen, T. Leth, and J. Reinholdt. 1996. The effect of microwave heating on vitamins $\mathrm{B} 1$ and $\mathrm{E}$, and linoleic and linolenic acids, and immunoglobulins in human milk. Int. J. Food Sci. Nutr. 47:427-436.

Quigley, J. D., III, C. J. Kost, and T. M. Wolfe. 2002. Absorption of protein and IgG in calves fed a colostrum supplement or replacer. J. Dairy Sci. 85:1243-1248.

Reber, A. J., A. R. Hippen, and D. J. Hurley. 2005. Effects of the ingestion of whole colostrum or cell-free colostrum on the capacity of leukocytes in newborn calves to stimulate or respond in oneway mixed leukocyte cultures. Am. J. Vet. Res. 66:1854-1860.

Reber, A. J., A. Lockwood, A. R. Hippen, and D. J. Hurley. 2006. Colostrum induced phenotypic and trafficking changes in maternal mononuclear cells in a peripheral blood leukocyte model for study of leukocyte transfer to the neonatal calf. Vet. Immunol. Immunopathol. 109:139-150.

Riedel-Caspari, G., and F. W. Schmidt. 1991a. The influence of colostral leukocytes on the immune system of the neonatal calf. I. Effects on lymphocyte responses. Dtsch. Tierarztl. Wochenschr. 98:102-107.

Riedel-Caspari, G., and F. W. Schmidt. 1991b. The influence of colostral leukocytes on the immune system of the neonatal calf. II. Effects on passive and active immunization. Dtsch. Tierarztl. Wochenschr. 98:190-194.

Riedel-Caspari, G., and F. W. Schmidt. 1991c. The influence of colostral leukocytes on the immune system of the neonatal calf. III. Effects on phagocytosis. Dtsch. Tierarztl. Wochenschr. 98:330334.

Riedel-Caspari, G., F. W. Schmidt, and J. Marquardt. 1991. The influence of colostral leukocytes on the immune system of the neonatal calf. IV. Effects on bactericidity, complement and interferon; synopsis. Dtsch. Tierarztl. Wochenschr. 98:395-398.

Saif, L. J., and K. L. Smith. 1985. Enteric viral infections of calves and passive immunity. J. Dairy Sci. 68:206-228.
Sheldrake, R. F., and A. J. Husband. 1985. Intestinal uptake of intact maternal lymphocytes by neonatal rats and lambs. Res. Vet. Sci. 39:10-15.

Sieber, R., P. Eberhard, D. Fuchs, P. U. Gallmann, and W. Strahm. 1996. Effect of microwave heating on vitamins A, E, B1, B2 and B6 in milk. J. Dairy Res. 63:169-172.

Smith, B. P. 2002. Large Animal Internal Medicine. 3rd ed. Mosby, St Louis, MO.

Smith, B. P., D. G. Oliver, P. Singh, G. Dilling, P. A. Martin, B. P. Ram, L. S. Jang, N. Sharkov, J. S. Orsborn, and K. Jacket. 1989 Detection of Salmonella dublin mammary gland infection in carrier cows, using an enzyme-linked immunosorbent assay for antibody in milk or serum. Am. J. Vet. Res. 50:1352-1360.

Spier, S. J., B. P. Smith, J. S. Cullor, H. J. Olander, L. D. Roden, and G. W. Dilling. 1991. Persistent experimental Salmonella dublin intramammary infection in dairy cows. J. Vet. Intern. Med. 5:341-350.

Stabel, J. R., S. Hurd, L. Calvente, and R. F. Rosenbusch. 2004. Destruction of Mycobacterium paratuberculosis, Salmonella spp., and Mycoplasma spp. in raw milk by a commercial on-farm hightemperature, short-time pasteurizer. J. Dairy Sci. 87:2177-2183.

Staley, T. E., and L. J. Bush. 1985. Receptor mechanisms of the neonatal intestine and their relationship to immunoglobulin absorption and disease. J. Dairy Sci. 68:184-205.

Stewart, S., S. Godden, R. Bey, P. Rapnicki, J. Fetrow, R. Farnsworth, M. Scanlon, Y. Arnold, L. Clow, K. Mueller, and C. Ferrouillet. 2005. Preventing bacterial contamination and proliferation during the harvest, storage, and feeding of raw bovine colostrum. J. Dairy Sci. 88:2571-2578.

Streeter, R. N., G. F. Hoffsis, S. Bech-Nielsen, W. P. Shulaw, and D. M. Rings. 1995. Isolation of Mycobacterium paratuberculosis from colostrum and milk of subclinically infected cows. Am. J. Vet. Res. 56:1322-1324.

Sweeney, R. W. 1996. Transmission of paratuberculosis. Vet. Clin. North Am. Food Anim. Pract. 12:305-312.

Tuboly, S., and S. Bernath. 2002. Intestinal absorption of colostral lymphoid cells in newborn animals. Adv. Exp. Med. Biol. 503:107-114. 